\title{
ESTIMASI VALIDITAS DAN RESPON SISWA TERHADAP BAHAN AJAR MULTI REPRESENTASI: DEFINITIF, MAKROSKOPIS, MIKROSKOPIS, SIMBOLIK PADA MATERI ASAM BASA
}

\author{
Cahya Wulandari $^{1}$, Endang Susilaningsih ${ }^{2}$, Kasmui $^{3}$
}

\begin{abstract}
This research aims to develop multi-representation teaching material that includes definitive, macroscopic, microscopic, and valid symbolic to determine students' responses through multi-representation material. This research was conducted at SMA Negeri 1 Karangtengah, with subjects in class XI IPA 3. This research was applied to acid-base materials. The data obtained in this research are the results of expert validation and students' responses to multi-representation media teaching material: definitive, macroscopic, microscopic, and symbolic. The data retrieval was conducted by expert judgement method to determine the validity of teaching materials, and the questionnaire method to determine student response through multirepresentation material: definitive, macroscopic, microscopic, symbolic was validated by three validators. The research outcome shows that multirepresentation media: definitive, macroscopic, microscopic, symbolic valid with an average score of 62 from a total score of 75 . The student responses through multi-representation material showed a positive response through the material.
\end{abstract}

Keywords: acid-base, multi representation, validity

\begin{abstract}
Abstrak
Penelitian ini bertujuan untuk menyusun bahan ajar multi representasi yang mencakup aspek definitif, makroskopis, mikroskopis, dan simbolik yang valid dan mengetahui respon siswa terhadap bahan ajar tersebut. Penelitian ini dilakukan di SMA Negeri 1 Karangtengah, dengan subjek kelas XI IPA 3. Penelitian ini diterapkan pada materi asam basa. Data yang diperoleh pada penelitian ini adalah hasil validasi ahli materi dan tanggapan siswa pada media bahan ajar multi representasi: definitif, makroskopis, mikroskopis, simbolik. Pengambilan data dilakukan dengan metode expert judgement untuk mengetahui validitas bahan ajar, dan metode angket untuk mengetahui respon siswa terhadap bahan ajar multi representasi. Bahan ajar multi representasi tersebut divalidasi oleh tiga validator. Hasil penelitian menunjukkan bahwa bahan ajar multi representasi valid dengan skor ratarata 62 dari skor total 75 . Respon siswa terhadap bahan ajar multi representasi menunjukkan respon positif.
\end{abstract}

Kata kunci: asam basa; multi representasi; validitas

Jurusan Kimia FMIPA Universitas Negeri Semarang

Email: ayawulandari19@gmail.com
(C)2018 Universitas Islam Negeri Walisongo 165

ISSN: 2088-7868, e-ISSN 2502-5708 


\section{PENDAHULUAN}

Kimia adalah salah satu cabang dari bidang ilmu sains. kimia mempunyai karakteristik tertentu yang membedakan dengan kajian ilmu lain. Karakteristik ilmu kimia antara lain: (1) sebagian besar konsepnya bersifat abstrak, sederhana, berjenjang, dan terstruktur; (2) merupakan ilmu untuk memecahkan masalah serta mendeskripsikan fakta fakta dan peristiwa-peristiwa (Mentari,2014). Kimia adalah ilmu yang mempelajari mengenai komposisi, struktur, dan sifat zat atau materi dari skala atom (mikroskopik) hingga molekul serta perubahan atau transformasi serta interaksi mereka untuk membentuk materi yang ditemukan sehari-hari. Pembelajaran kimia di sekolah bertujuan menguasai standar kompetensi yang telah ditetapkan, oleh karena itu pembelajaran kimia harus dibuat lebih menarik dan mudah dipahami, karena kimia lebih membutuhkan pemahaman dari pada penghafalan berbagai rumus yang begitu banyak (Prabowowati, 2014). Sehingga pembelajaran kimia perlu di dukung media pembelajaran yang sesuai.

Media Pembelajaran memegang peranan yang penting dalam proses pembelajaran. Penggunaan media pembelajaran dapat membantu dalam menyampaikan materi pembelajaran (Nur, 2017). Hamalik (2012) mengemukakan bahwa pemakaian media pembelajaran dalam proses belajar mengajar dapat mengurangi kekacauan dalam penafsiran materi, memusatkan perhatian siswa saat kegiatan belajar mengajar, membangkitkan keinginan dan minat yang baru, membangkitkan motivasi pembelajaran, serta menciptakan lingkungan belajar yang menyenangkan. Media pembelajaran adalah suatu alat yang digunakan untuk membantu tenaga pendidik dalam menyampaikan informasi kepada siswa (Rahmawan, 2013).

Media pembelajaran dapat berupa audio, visual dan audio visual. Diantara jenis media ajar visual antara lain: handout, buku, modul, lembar kerja siswa, brosur, leaflet, wallchart, foto/gambar, dan non cetak (non printed), seperti model/ maket (Yotiani, 2016). Bahan ajar merupakan salah satu media dalam pembelajaran yang berisi informasi materi pelajaran, gambar-gambar dan penjelasan konsep (Ekawarna, 2007). Bahan ajar diperlukan dalam pembelajaran karena berfungsi sebagai pedoman bagi pendidik, pedoman belajar siswa, dan pedoman evaluasi (Majid, 2009). Penggunaan bahan ajar memberikan pondasi kepada siswa untuk berpikir konseptual, memotivasi untuk belajar dan menangkap imajinasi yang digunakan dengan benar (Nwike, 2013). 
Bahan ajar berupa buku teks mampu membantu siswa untuk meningkatkan pemahaman secara ilmiah (Niaz, 2005). Sehingga sangat membantu siswa untuk mempelajari mata pelajaran kimia.

Pelajaran kimia bagi sebagian siswa merupakan pelajaran yang dianggap sulit untuk dipahami, kurang menarik, dan tidak relevan. Salah satu penyebabnya adalah kurang minat dan motivasi siswa, siswa merasa terpaksa atau hanya sebagai suatu kewajiban. Selain itu, karakteristik dari konsep-konsep ilmu kimia yang bersifat abstrak juga menyebabkan kimia sulit untuk dipelajari. Salah satu materi kimia yang bersifat abstrak dan dianggap sulit oleh sebagian besar siswa adalah materi asam basa. Pemahaman konsep kimia diperlukan visualisasi konsep yang abstrak, penjelasan konsep harus multirepresentasi, instrumen tes harus memadai disesuaikan dengan strategi pembelajaran yang digunakan (Mardapi, 2008). Ilmu kimia perlu memperhatikan fenomena kimia yang direpresentasikan menjadi tiga level, yaitu level makroskopik, sub-mikroskopik, dan simbolik (Afriansi, 2014).

Multi representasi merupakan bentuk representasi yang memadukan antara teks, gambar nyata, atau grafik (Sunyono, 2011). Representasi adalah kemampuan siswa mengkomunikasikan ide/gagasan yang dipelajari dengan cara tertentu (Hutagaol, 2013). Representasi kimia dikembangkan berdasarkan urutan dari fenomena yang dilihat, persamaan reaksi, model atom dan molekul, dan simbol (Herawati, 2013). Larsy (2007) menyatakan bahwa menggunakan multi representasi dapat mendukung proses pengamatan dengan kompetensi yang berbeda. Yazid (2012) menyatakan bahwa representasi bertujuan untuk mempermudah siswa dalam menyelesaikan masalah matematika yang bersifat abstrak menjadi lebih konkrit pada siswa.

Bahan ajar multi representasi: definitif, makroskopis, mikroskopis, simbolik ini berbeda dengan bahan ajar yang lain. Bahan ajar ini mengandung unsur definitif seperti definisi materi, unsur makroskopis yaitu apa yang dapat terlihat oleh mata, unsur mikroskopis yaitu apa yang sebenarnya terjadi dalam larutan, dan unsur simbolik yaitu berupa simbol-simbol dan persamaan reaksi. Oleh karena itu tujuan penelitian ini adalah untuk menyusun bahan ajar yang mencakup aspek definitif, makroskopis, mikroskopis, dan simbolik pada materi asam basa yang valid dan untuk mengetahui respon siswa terhadap bahan ajar multi representasi. 


\section{METODE PENELITIAN}

Metode pengumpulan data pada penelitian ini adalah expert judgement dan angket. Bahan ajar multi representasi yang meliputi definitif, makroskopis, mikroskopis, simbolik divalidasi kontennya oleh validator. Validator dalam hal ini adalah ahli materi. Validator yang digunakan dalam penelitian ini sejumlah 3 orang. Angket digunakan untuk mengetahui respon siswa terhadap bahan ajar multi representasi: definitif, makroskopis, mikroskopis, simbolik.

\section{HASIL DAN PEMBAHASAN}

Bahan ajar yang digunakan dalam penelitian ini adalah bahan ajar multi representasi. Bahan ajar ini mencakup aspek definitif, makroskopis, mikroskopis dan simbolik. Desain cover bahan ajar multi representasi disajikan dalam Gambar 1. Aspek definitif adalah definisi suatu konsep. Contohnya definisi teori asam basa Arrhenius, teori asam basa Bronsted-Lowry, teori asam basa Lewis. Aspek definitif dalam bahan ajar multi representasi disajikan dalam Gambar 2. Aspek Makroskopis adalah konsep bersifat nyata dan mengandung bahan kimia yang kasat mata dan nyata. Contohnya perubahan warna kertas lakmus dan indikator bahan alam. Aspek makroskopis dalam bahan ajar multi representasi disajikan dalam Gambar 3.

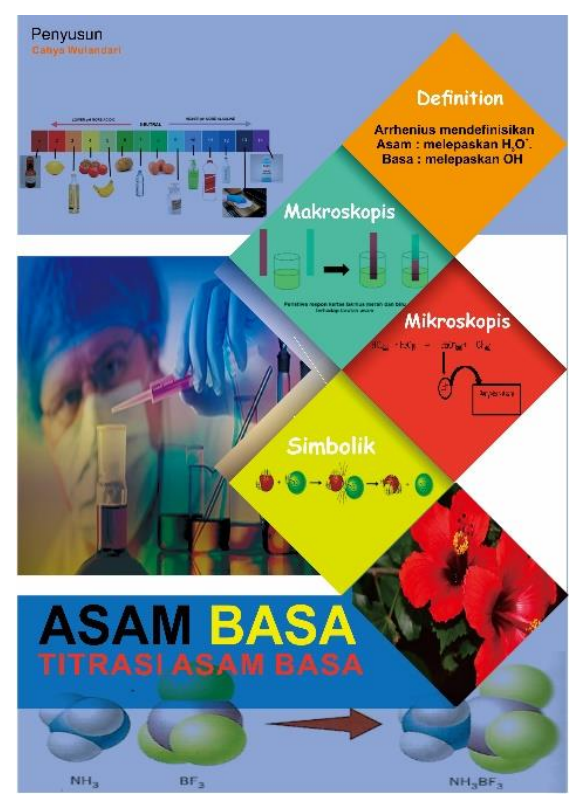

Gambar 1. Desain Cover Bahan Ajar Multi Representasi 


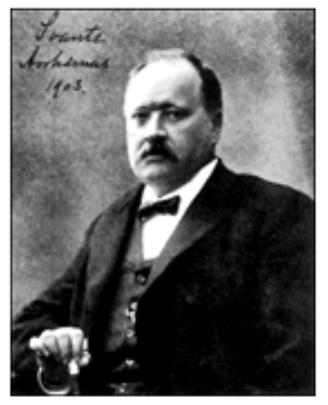

\section{Definition:}

Arrhenius mendefinisikan

Asam: merupakan zat yang dalam air dapat melepaskan ion hidronium $\left(\mathrm{H}_{3} \mathrm{O}^{+}\right)$.

Basa : merupakan zat yang di dalam air dapat melepaskan ion hidroksida $\left(\mathrm{OH}^{-}\right)$.

Gambar 2.Contoh Aspek Definitif
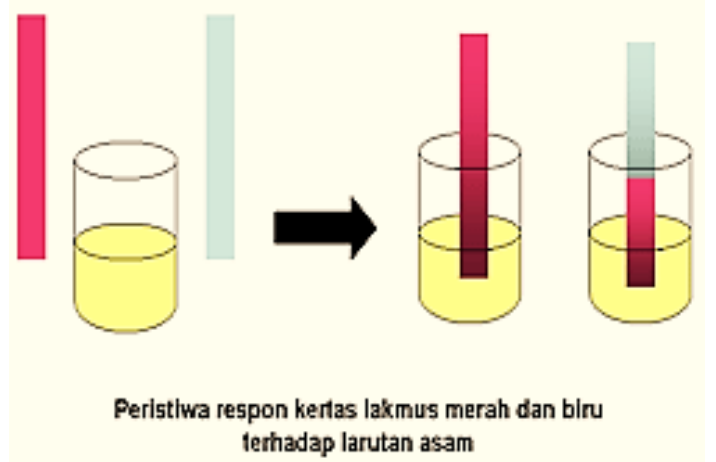

\section{.} erhadap larutan asam

\section{Gambar 3.Contoh Aspek Makroskopis}

Berdasarkan Gambar 3. dapat dilihat bahwa indikator kertas lakmus menunjukkan respon yang berbeda terhadap larutan asam dan larutan basa. Dalam larutan asam, lakmus merah tetap merah sedangkan lakmus biru berubah menjadi merah. Dalam larutan basa, lakmus merah berubah menjadi biru sedangkan lakmus biru tetap biru.

Aspek Mikroskopis adalah konsep nyata tetapi tidak kasat mata yang terdiri dari tingkat partikulat yang dapat digunakan untuk menjelaskan reaksi-reaksi kimia. Contohnya menurut Arrhenius dalam air Asam klorida terurai menjadi ion-ionnya, dan masih banyak lagi contoh yang lain. Aspek mikroskopis dalam bahan ajar multi representasi disajikan dalam Gambar 4.

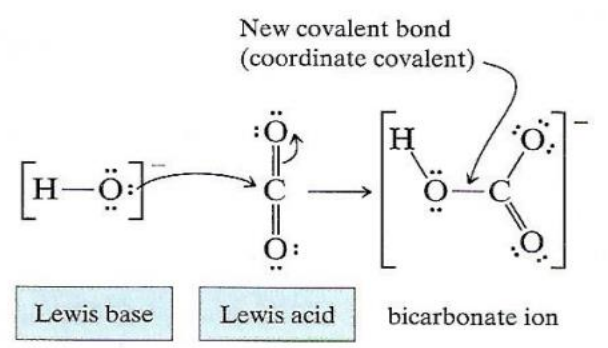

Gambar 4.Contoh Aspek Mikroskopis 
Gambar 4 menunjukkan reaksi antara ion hidroksida dengan karbon dioksida. Menurut Lewis ion hidroksida bertindak sebagai basa, karena ion hidroksida memiliki pasangan elektron bebas. Pasangan elektron bebas tersebut digunakan bersama karbon dioksida sehingga terbentuklah ikatan kovalen koordinasi. Karbon dioksida bertindak sebagai asam, karena memiliki orbital kosong. Orbital kosong tersebut digunakan untuk berikatan kovalen koordinasi dengan ion hidroksida.

Aspek Simbolik adalah gambar-gambar dan lambang yang membantu menjelaskan konsep yang abstrak. Contoh aspek simbolik adalah Asam Klorida memiliki lambang $\mathrm{HCl}$, dan masih banyak lagi contoh yang lainnya. Aspek simbolik dalam bahan ajar multi representasi disajikan dalam Gambar 5.



Gambar 5.Contoh Aspek Simbolik

Gambar 5 menunjukkan reaksi antara $\mathrm{NH}_{3}$ dengan $\mathrm{BF}_{3}$ membentuk $\mathrm{NH}_{3} \mathrm{BF}_{3}$. Menurut Lewis $\mathrm{NH}_{3}$ berperan sebagai basa, sedangkan $\mathrm{BF}_{3}$ bertindak sebagai asam. $\mathrm{NH}_{3}$ merupakan basa karena dapat memberikan 1 pasang elektron terhadap $\mathrm{BF}_{3}$ untuk digunakan secara bersama dalam senyawa $\mathrm{NH}_{3} \mathrm{BF}_{3}$, sehingga $\mathrm{BF}_{3}$ bersifat asam.

Bahan ajar multi representasi yang meliputi definitif, makroskopis, mikroskopis, simbolik divalidasi kontennya oleh validator. Validator dalam hal ini adalah ahli materi. Validator yang digunakan dalam penelitian ini sejumlah 3 orang. Skor validasi ahli materi disajikan dalam Tabel 1.

Tabel 1. Rekapitulasi Skor Validasi Ahli Materi

\begin{tabular}{cc}
\hline Validator & Skor (Skor Total 75) \\
\hline A & 61 \\
B & 62 \\
C & 63 \\
Rata-rata & 62 \\
\hline
\end{tabular}


Bahan ajar multi representasi dapat dikatakan valid. Dalam penelitian ini bahan ajar dapat dikatakan valid dengan skor antara 51 sampai 75. Kategori kelayakan bahan ajar disajikan dalam Tabel 2. Berdasarkan Tabel 2 bahan ajar multi representasi dapat dikatakan valid karena memiliki skor rata-rata 62 dari skor total 75.

Tabel 2. Kategori Kelayakan Bahan Ajar

\begin{tabular}{cc}
\hline Kategori & Skor \\
\hline Sangat Layak & $63<\mathrm{x} \leq 75$ \\
Layak & $51<\mathrm{x} \leq 63$ \\
Cukup Layak & $39<\mathrm{x} \leq 51$ \\
Kurang Layak & $27<\mathrm{x} \leq 39$ \\
Tidak Layak & $15<\mathrm{x} \leq 27$ \\
\hline
\end{tabular}

Respon siswa terhadap bahan ajar multi representasi: definitif, makroskopis, mikroskopis, simbolik diukur menggunakan instrumen angket. Hasil respon siswa terhadap bahan ajar multi representasi menunjukkan respon positif. Respon siswa terhadap bahan ajar multi representasi disajikan dalam Tabel 3.

Tabel 3. Respon Siswa Terhadap Bahan Ajar

\begin{tabular}{ccccc}
\hline \multirow{4}{*}{ Butir } & \multicolumn{4}{c}{ Respon Siswa } \\
\cline { 2 - 5 } & $\begin{array}{c}\text { Sangat Baik } \\
(\%)\end{array}$ & Baik $(\%)$ & Cukup Baik $(\%)$ & Kurang Baik (\%) \\
\hline 1 & 65,79 & 34,21 & 0 & 0 \\
2 & 53,84 & 46,46 & 0 & 0 \\
3 & 61,54 & 33,33 & 5,13 & 0 \\
4 & 35,89 & 61,53 & 2,58 & 0 \\
5 & 53,84 & 46,46 & 0 & 0 \\
6 & 48,71 & 48,71 & 2,58 & 0 \\
7 & 48,71 & 51,29 & 0 & 0 \\
8 & 17,95 & 76,92 & 5,13 & 0 \\
9 & 53,84 & 46,46 & 0 & 0 \\
10 & 17,95 & 82,05 & 0 & 0 \\
11 & 53,84 & 46,46 & 0 & 0 \\
12 & 33,33 & 61,53 & 5,14 & 0 \\
13 & 35,89 & 64,11 & 0 & 0 \\
14 & 51,29 & 48,71 & 0 & 0 \\
15 & 38,46 & 61,54 & 0 & 0 \\
\hline
\end{tabular}




\section{SIMPULAN}

Bahan ajar yang digunakan dalam penelitian ini adalah bahan ajar multi representasi. Bahan ajar multi representasi mengandung aspek definitif, makroskopis, mikroskopis, dan simbolik. Bahan ajar multi representasi: definitif, makroskopis, mikroskopis, simbolik pada materi asam basa valid dengan skor 62 dari skor total 75 dan respon siswa menunjukkan reaksi positif terhadap bahan ajar multi representasi. 


\section{DAFTAR PUSTAKA}

Afriansi, Enggar Afrim. (2014). Pengembangan LKS Berbasis Representasi Level Submikroskopik Pada Materi Sistem Koloid Kelas XI SMA Negeri 1 Taman Sidoarjo. UNESA Journal of Chemical Education, 3(3).

Ekawarna. (2007). Mengembangkan bahan ajar mata kuliah permodalan koperasi untuk meningkatkan motivasi dan hasil belajar mahasiswa. Jurnal Makara : Sosial Humaniora, 11(1), 42-47.

Hamalik, O. (2012). Psikologi Belajar dan Mengajar. Bandung: Sinar Baru Algesindo.

Herawati, Rosita Fitri. (2013). Pembelajaran Kimia Berbasis Multiple Representasi Ditinjau Dari Kemampuan Awal Terhadap Prestasi Belajar Laju Reaksi Siswa Sma Negeri I Karanganyar Tahun Pelajaran 2011/2012. Jurnal Pendidikan Kimia (JPK), 2(2).

Hutagaol, Kartini. (2013). Pembelajaran Kontekstual untuk Meningkatkan Kemampuan Representasi Matematis Siswa Sekolah Menengah Pertama. Jurnal Ilmiah Program Studi Matematika STKIP Siliwangi Bandung, 2(1).

Majid, Abdul. (2009). Perencanaan Pembelajaran Mengembangkan Standar Kompetensi Guru. Bandung: Remaja Rosdakarya.

Mardapi, Djemari (2008). Penyusunan Tes Hasil Belajar. Yogyakarta: Program Pasca Sarjana Universitas Negeri Yogyakarta.

Mentari, Luh. (2014). Analisis Miskonsepsi Siswa SMA pada Pembelajaran Kimia untuk Materi Larutan Penyangga. E-journal Kimia Visvitalis Universitas Pendidikan Ganesha, 2(1).

Niaz, M. 2005. How to Facilitate Students Conceptual Understanding of Chemistry History and Philosophy of Science Perspective. Chemical Education International, 6(1).

Nur, Achmad Vandian. (2017). Pengaruh Penggunaan Metode Pembelajaran Guided Note Taking Berbantuan Media Kimmy-Games Terhadap Pemahaman Konsep Kimia Siswa SMA. Jurnal Inovasi Pendidikan Kimia, 11(1).

Nwike, Matthew C. (2013). Effects of Use of Instructional Materials on Students Cognitive Achievement in Agricultural Science. Journal of Educational and Social Research, 3.

Prabowowati, Kartika. (2014). Penerapan Media Chemscool Dengan Metode Guided Note Taking Pada Pemahaman Konsep Siswa. Jurnal Inovasi Pendidikan Kimia, $8(2)$.

Rahmawan, Adji Dovan Tri. (2013). Pengaruh Penerapan Media Animasi Terhadap Pergeseran Konsep Siswa Pada Ketiga Level Representatif Kimia (Makroskopis, Submikroskopis, Dan Simbolik) Pada Materi Pokok Larutan Penyangga Untuk Siswa Kelas XI SMA N 1 Kertosono Nganjuk. Unesa Journal of Chemical Education, 2(2).

Sunyono. (2011). Kajian Tentang Peran Multipel Representasi Pembelajaran kimia dalam pengembangan Model Mental Siswa. Makalah Seminar Nasional Pendidikan : Surabaya. 
Yazid, A. (2012). Pengembangan Perangkat Pembelajaran Matematika Model Kooperatif dengan Strategi TTW (ThinkTalk- Write) pada Materi Volume Bangun Ruang Sisi Datar. Journal of Primary Educational, 1(1).

Yotiani. (2016). Pengembangan Bahan Ajar Hidrolisis Garam Bermuatan Karakter Berbasis Inkuiri Terbimbing Untuk Meningkatkan Kemampuan Berpikir Kritis Siswa. Jurnal Inovasi Pendidikan Kimia, 10(2). 